\title{
Postglacial, relative shore-level changes in Lillebælt, Denmark
}

\author{
Ole Bennike and Jørn Bo Jensen
}

The brackish Baltic Sea and the more saline Kattegat are connected by three straits, Lillebælt, Storebælt and Øresund (Fig. 1). Of the three straits, Lillebælt is the narrowest, with $700 \mathrm{~m}$ at its narrowest point, widening out towards the south to around $25 \mathrm{~km}$ (Fig. 2). In the narrow parts of Lillebælt, water depths around $30-50 \mathrm{~m}$ are common. In the northern part of Lillebælt the depth is $16-18 \mathrm{~m}$ and in the southern part the depth is around $35 \mathrm{~m}$. Storebælt and Øresund have played important roles as outlets during the history of the Baltic Sea, and their histories have been much discussed (Björck 1995; Bennike et al. 2004). In contrast, Lillebælt has received little attention. In this paper we present 11 new radiocarbon accelerator mass spectrometry (AMS) ages and propose a curve for Holocene relative shore-level changes in Lillebælt. We use the term shore-level changes rather than sea-level changes because we have constructed both lake-level and sea-level changes.

During the last deglaciation of the Lillebælt region, large channels were eroded by northward-flowing subglacial meltwater. These channels are now found at the bottom of the strait, and most of them are kept free of sediments by strong bottom currents. However, late and postglacial

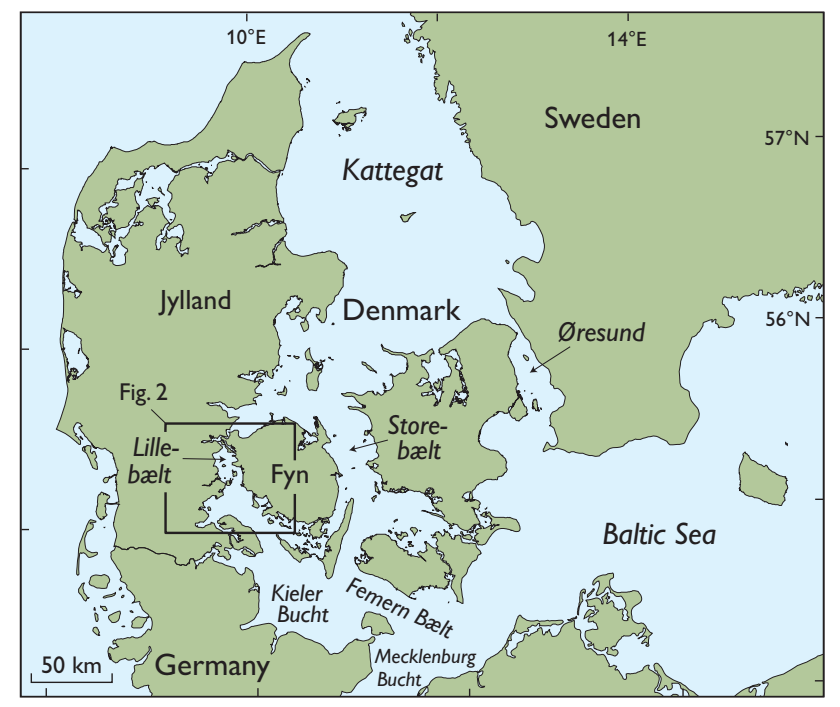

Fig. 1. Map of Denmark and surrounding area showing the location of Lillebælt and the other straits connecting the Baltic Sea to Kattegat, as well as place names mentioned in the text. sediments are found in some parts of the channels. Several submerged settlements have been reported from the Lillebælt region (Andersen 1985). They are dated to the mid-Holocene from artefacts and by radiocarbon dating.

\section{Methods}

Combined high-resolution, sub-bottom profiling and sediment coring were carried out from R/V Alexander von Humboldt. The seismo-acoustic equipment included a sediment echosounder (Fig. 3), and the profiles obtained were used for the selection of the core sites (Fig. 4). A $6 \mathrm{~m}$ long vibrocorer was used for coring. We also had access to vibrocores and seismic profiles from a survey conducted in connection with a planned gas pipeline. This material was handed over to the Geological Survey of Denmark and Greenland (GEUS) from Dansk Olie og Naturgas A/S.

Selected cores with the most complete stratigraphy were sub-sampled for studies of macrofossils. The samples were wet sieved and analysed using a dissecting microscope. Re-

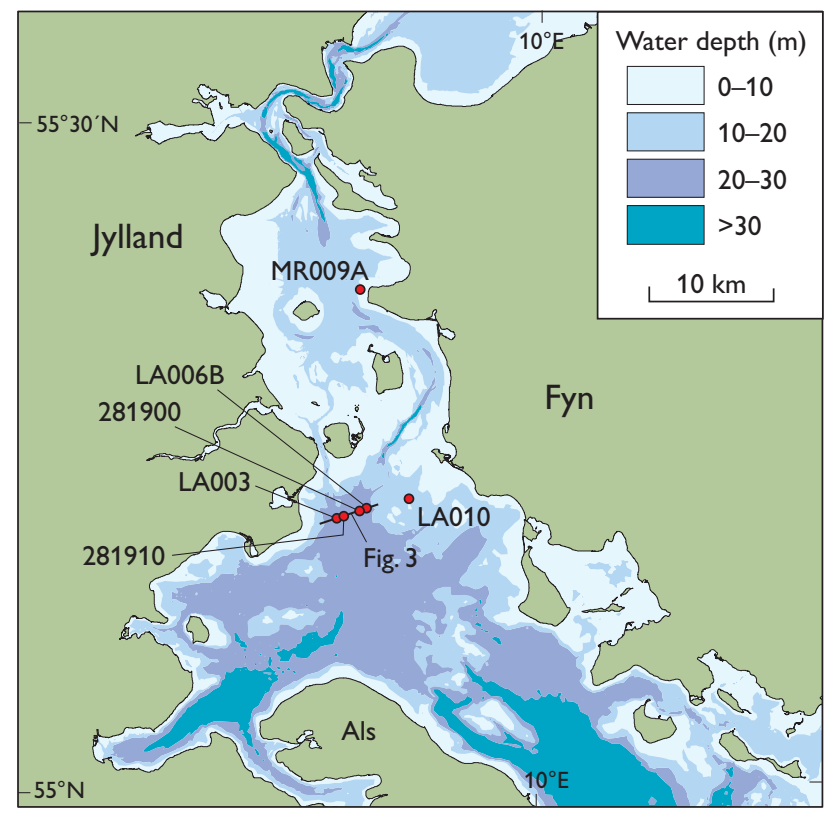

Fig. 2. Bathymetry of Lillebælt with the location of the vibrocores indicated. 


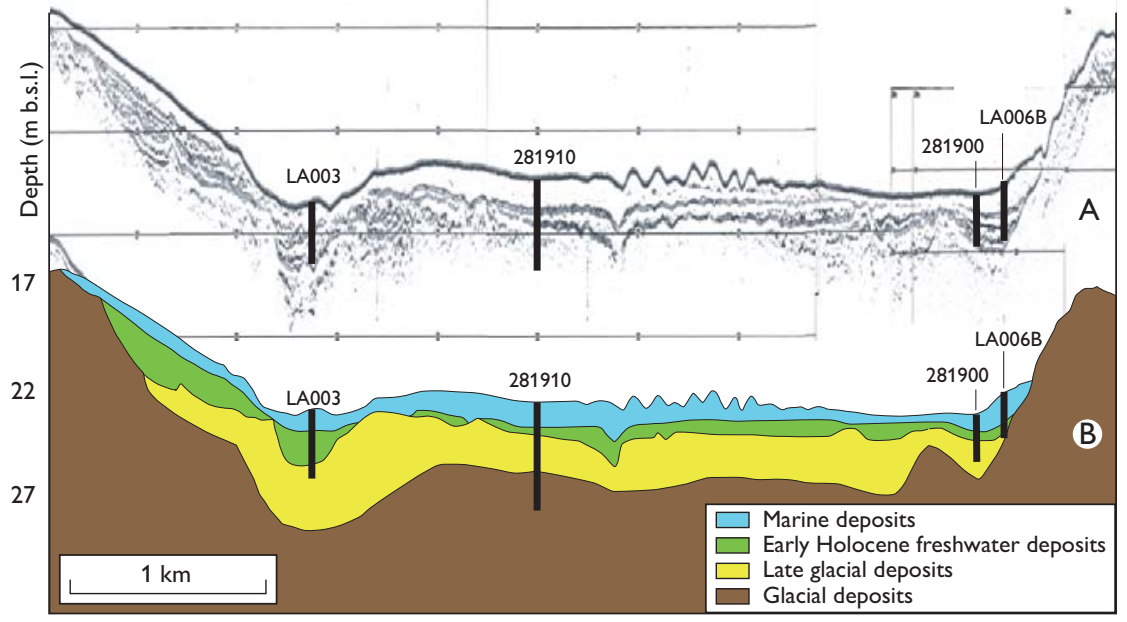

Fig. 3. A: Original seismic profile, obtained by a sediment echosounder. B: Interpretation below. For location see Fig. 2. Cores labelled 2819xx were collected from R/V Alexander von Humboldt, and cores labelled LA were collected for Dansk Olie og Naturgas A/S. mains of plants and marine molluscs were submitted for AMS radiocarbon dating (Table 1). Several published dates were also used for the reconstruction of shore-level changes (Table 2; K-samples are conventional ages, and the LuS-sample is an AMS age). We have used a reservoir age of 400 years for the marine samples, however, the reservoir age may have varied somewhat during the Holocene (Olsen et al. 2009).

\section{Sediments, palaeoecology and chronology}

The oldest sediments consist of till that shows an internal, chaotic reflection pattern and a sharp upper boundary. A few cores also penetrated meltwater sand. Till and meltwater sand accumulated during the last glaciation and deglaciation of the region.

The glacial deposits are locally overlain by late glacial sediments, which are found in the channels. The late glacial sediments show conformable internal reflectors, and con- sist of clay, silt and fine-grained sand. One sample has been dated to 11 400-11900 cal. years BP, corresponding to a late Younger Dryas age (Table 1, Poz-8924). We suggest that the late glacial sediments were partly deposited in a branch of the Baltic Ice Lake.

In the deeper parts of Lillebælt, black, organic-rich sediments are widespread. The sediments are commonly laminated and may contain abundant fragments of small roots and fruits of telmatic plants. Some of this sediment is swamp peat, but most of it is coarse detritus gyttja. The organic-rich sediments are usually overlain by laminated calcareous gyttja clay. However, in core LA006B lake sediments are found below peat. This succession is interpreted as overgrowing of a basin. Samples from the lake deposits gave ages of $c$. 11 000-8800 cal. years BP (early Holocene, Table 1, Poz-5754, Poz-5755, Poz-5753, Poz-8859, Poz8860).
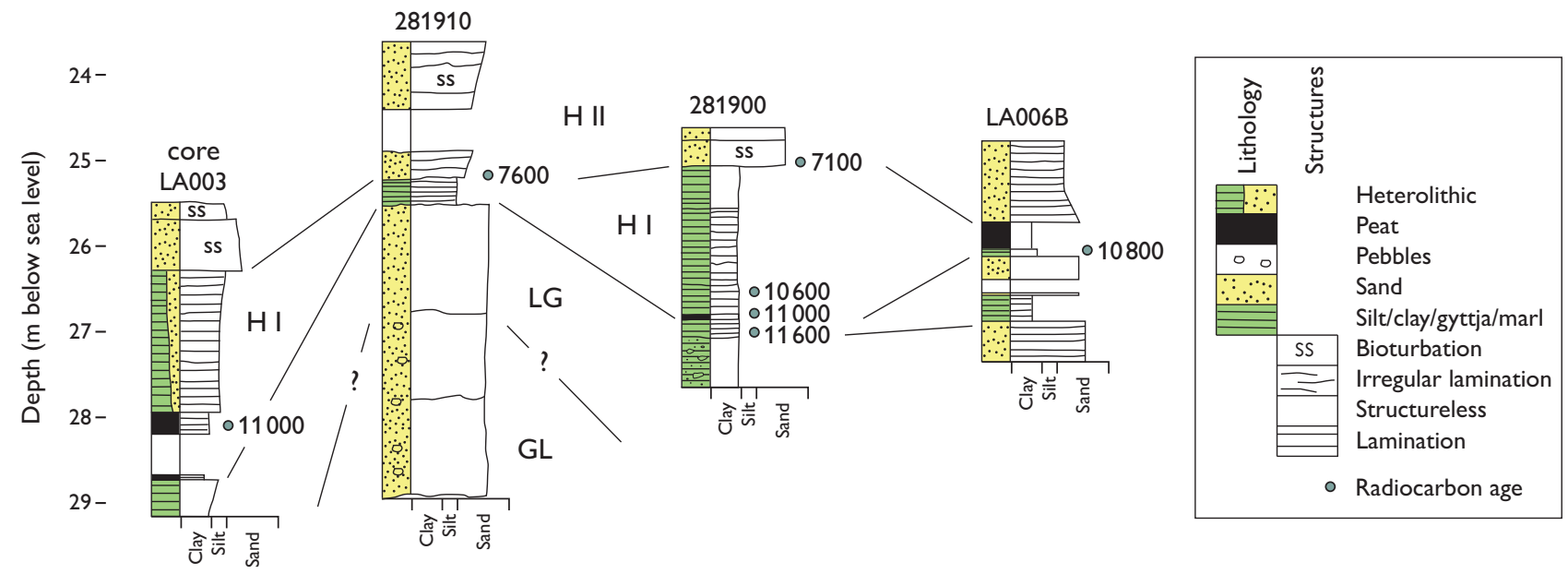

Fig. 4. Sedimentological logs from vibrocores from the Lillebælt. Radiocarbon ages are in calibrated calendar years BP. GL: glacial. LG: late glacial. H I: early Holocene freshwater. H II: brackish and marine Holocene deposits. 
Table 1. New radiocarbon AMS age determinations from Lillebælt

\begin{tabular}{|c|c|c|c|c|c|c|}
\hline $\begin{array}{l}\text { Core } \\
\text { no. }\end{array}$ & $\begin{array}{c}\text { Laboratory } \\
\text { no. }\end{array}$ & Species* & Sediment & $\begin{array}{l}\text { Depth } \\
\text { b.s.l. }(\mathrm{m})\end{array}$ & $\begin{array}{l}\text { Age }\left({ }^{14} C\right. \\
\text { years } B P)\end{array}$ & $\begin{array}{c}\text { Calibrated } \\
\text { age (years BP) }\end{array}$ \\
\hline LA003 & Poz-5754 & $\begin{array}{c}\text { M. trifoliata, C. mariscus } \\
\text { P. australis }\end{array}$ & Detritus gyttja & $28.10-28.20$ & $9670 \pm 50$ & $10789-11210$ \\
\hline LA006B & Poz-5755 & M. trifoliata, C. mariscus & Lake marl & $26.02-26.03$ & $9460 \pm 50$ & $10567-11068$ \\
\hline LA010 & Poz-5767 & B. Albae, C. mariscus & Brackish sand & $16.60-16.70$ & $7700 \pm 70$ & $8384-8599$ \\
\hline LA010 & Poz-5753 & M. trifoliata, C. mariscus & Lake gyttja & $16.72-16.78$ & $7880 \pm 50$ & $8556-8976$ \\
\hline MR009A & Poz-5790 & Mytilus edulis & Marine mud & 9.70 & $7280 \pm 40$ & $7842-7649$ \\
\hline MR009A & Poz-5805 & B. Albae & Peat & $9.80-9.90$ & $7420 \pm 50$ & $8074-8372$ \\
\hline 281900 & Poz-8820 & Arctica islandica & Marine sand & $25.00-25.05$ & $6590 \pm 40$ & 6994-7225 \\
\hline 281900 & Poz-8859 & P. tremula, B. nana & Lake clay & $26.50-26.60$ & $9350 \pm 50$ & $10419-10702$ \\
\hline 281900 & Poz-8860 & P. tremula, B. Albae & Detritus gyttja & $26.80-26.88$ & $9670 \pm 50$ & 10 789-11210 \\
\hline 281900 & Poz-8924 & Salix sp. & Clay & $26.98-27.08$ & $10110 \pm 60$ & $11401-11910$ \\
\hline 281910 & Poz-8821 & M. edulis, M. balthica & Marine sand & $25.25-25.26$ & $7140 \pm 40$ & $7528-7692$ \\
\hline
\end{tabular}

* Full names are: Menyanthes trifoliata, Cladium mariscus, Phragmites australis, Betula sect. Albae, Betula nana, Populus tremula, Mytilus edulis, Macoma balthica. ${ }^{\S}$ Calibration is according to the INTCAL09 dataset (terrestrial samples) and the Marine09 dataset (marine samples).

Marine sediments from protected areas consist of laminated or bioturbated, fine-grained, organic-rich mud. Sandy and silty sediments are found in shallow water areas and in areas with strong bottom currents (Fig. 3). Shells and shell fragments of marine molluscs are common. On the acoustic records, the marine deposits are mostly transparent or show continuous reflectors parallel to the lower boundary. In three cores we dated the lowermost shell of marine molluscs we could find. The oldest age determination is $c .7700 \mathrm{cal}$. years BP (Table 1, Poz-5790).

In core LA010 bioturbated sand is present in the upper part of the core. The fauna implies brackish conditions. A sample from the bottom of the sand unit was dated to $c .8500$ cal. years BP (Table 1, Poz-5767). We suggest that the sand marks the first marine influence in the area.

\section{Shore-level changes}

On the basis of the available radiocarbon ages, we have reconstructed relative shore-level changes in the region (Fig. 5). The relative shore level was low during the early part of the Holocene and probably rose slowly throughout the early Holocene, and at the same time a large lake existed in the area. As the shore level rose this lake increased in size and at around $8500 \mathrm{cal}$. years BP it was transformed into a brackish water body. Two dates from core MR009A provide an important fix point for the shore-level evolution (Table 1). The dates show that a peat now found $9 \mathrm{~m}$ below sea level was transgressed by the sea between $c .8200$ and $c .7700 \mathrm{cal}$. years BP, and around 8000 cal. years BP marine conditions were established.

Later sea-level changes are constrained by six published radiocarbon dates (Table 2). They comprise two dates of wood from marine gyttja, two dates from Ostrea edulis shells, an age from a bone found in a grave at a water depth of $2.7 \mathrm{~m}$ and a bone of harp seal from a submarine settlement. The two latter dates come from sites that were situated above the contemporary sea level.

\section{Discussion}

In Lillebælt, late glacial sediments are found in incised channels. The Younger Dryas sequence that consists of finegrained laminated clay and silt is followed by a hiatus which was probably formed during the final drainage of the Baltic Ice Lake, when shore level dropped around $25 \mathrm{~m}$ over a few years (Björck 1995). The maximum shore level of the Baltic Ice Lake in the south-western Baltic Sea was around $20 \mathrm{~m}$ b.s.l., and this lake may have extended as far west as southwestern Kieler Bucht (Jensen et al. 2002). The Baltic Ice Lake may also have extended into southern Lillebælt.

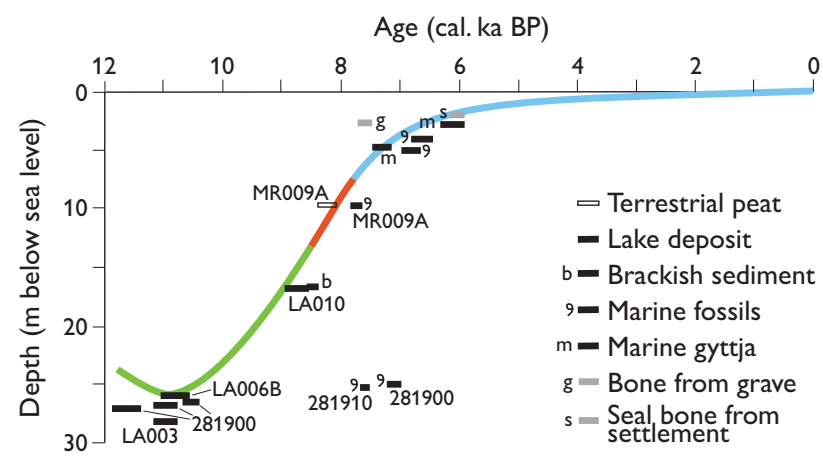

Fig. 5. Curve showing relative shore-level changes in southern Lillebælt during the Holocene. Green: lake phase. Red: brackish water phase. Blue: marine phase. ka: 1000 years. 
Table 2. Published radiocarbon age determinations from Lillebælt

\begin{tabular}{|c|c|c|c|c|c|}
\hline $\begin{array}{l}\text { Laboratory } \\
\text { no. }\end{array}$ & Material & $\begin{array}{l}\text { Depth } \\
\text { b.s.l. }(\mathrm{m})\end{array}$ & $\begin{array}{l}\text { Age }\left({ }^{14} \mathrm{C}\right. \\
\text { years BP) }\end{array}$ & $\begin{array}{c}\text { Calibrated } \\
\text { age (years BP)* }\end{array}$ & Reference \\
\hline $\mathrm{K}-3558$ & Human bone & 2.7 & $6740 \pm 80$ & $7459-7727$ & Andersen (1985) \\
\hline K-4150 & Alnus wood & 4.7 & $6380 \pm 100$ & $7153-7480$ & Andersen (1985) \\
\hline K-4149 & Tilia wood & 2.8 & $5370 \pm 100$ & $5922-6317$ & Andersen (1985) \\
\hline K-5680 & Ostrea edulis shells & 5.0 & $5940 \pm 70$ & $6645-6995$ & Petersen \& Rasmussen (1995) \\
\hline K-5681 & Ostrea edulis shells & 4.0 & $5780 \pm 70$ & $6445-6797$ & Petersen \& Rasmussen (1995) \\
\hline LuS-6136 & Phoca groenlandica bone & 2.0 & $5595 \pm 50$ & $5885-6144$ & Bennike et al. (2008) \\
\hline
\end{tabular}

*Calibration is according to the INTCAL09 dataset (terrestrial samples) and the Marine09 dataset (marine samples).

During the earliest Holocene, large parts of Lillebælt were dry land, but local bogs and lakes must have existed in the deeper parts. As the shore level began to rise, local lakes and bogs became widespread. During continued shore-level rise, bogs were transformed into lakes, and a large lake developed in the southern part of Lillebælt. It was connected to another large lake to the south in Kieler Bucht, and to other large lakes in Femer Bælt, Mecklenburg Bucht and Storebælt.

Later, the ongoing eustatic sea-level rise led to brackish and then to marine conditions in Lillebælt. The first marine influence was via Storebælt when southern Lillebælt was a fjord. However, the fjord was transformed into the Lillebælt strait during continued rapid sea-level rise. The oldest dated marine shell from Lillebælt is from 7700 cal. years BP, but brackish water conditions are suggested at 8600-8384 cal. years BP. The youngest lake deposits (around $17 \mathrm{~m}$ below sea level) are dated to 8976-8556 cal. years BP. In Storebælt, the oldest dated marine shell gave an age of 8100 cal. years BP (Bennike et al. 2004), and in the Mecklenburg Bucht, the oldest shell date is $c .8000$ cal. years BP (Rößler et al. 2011). The early Holocene deposits in Lillebælt show no indication of a lowering of the shore level before being inundated by marine waters.

\section{Conclusions}

Glacial till and Holocene marine deposits are widespread in Lillebælt. In the deeply incised channels late glacial and early Holocene non-marine deposits are found, these units are separated by an erosional boundary. The late glacial deposits were probably deposited during pre-Allerød and Allerød times, as well as during the Younger Dryas. The early Holocene non-marine deposits have yielded ages between 11000 and 8800 cal. years BP.
The late glacial unit consists of lake deposits, and we suggest that the Baltic Ice Lake extended into southern Lillebælt. During the early Holocene, a large lake existed in southern Lillebælt; this lake expanded in size during shorelevel rise. The oldest shell of a marine mollusc from Lillebælt is dated to 7700 cal. years BP, but brackish conditions were probably established at around 8500 cal. years BP.

\section{Acknowledgement}

The captain and crew of R/V Alexander von Humboldt, and in particular the cruise leader, the late Wolfram Lemke are thanked for their help during the marine cruise.

\section{References}

Andersen, S.H. 1985: Tybrind Vig, a preliminary report on a submerged Ertebølle settlement on the west coast of Fyn. Journal of Danish Archaeology 4, 52-69.

Bennike, O., Jensen, J.B., Lemke, W., Kuijpers, A. \& Lomholt, S. 2004: Late- and postglacial history of the Great Belt, Denmark. Boreas 33, $18-33$.

Bennike, O., Rasmussen, P. \& Aaris-Sørensen, K. 2008: The harp seal (Phoca groenlandica Erxleben) in Denmark, southern Scandinavia, during the Holocene. Boreas 37, 263-272.

Björck, S. 1995: A review of the history of the Baltic Sea, 13.0-8.0 ka BP. Quaternary International 27, 19-40.

Jensen, J.B., Kuijpers, A., Bennike, O., Laier, T. \& Werner, F. 2002: New geological aspects for freshwater seepage and formation in Eckernförde Bay, western Baltic. Continental Shelf Research 22, 2159-2173.

Olsen, J., Rasmussen, P. \& Heinemeier, J. 2009: Holocene temporal and spatial variation in the radiocarbon reservoir age of three Danish fjords. Boreas 38, 458-470.

Petersen, K.S. \& Rasmussen, K.L. 1996: The impact of radiocarbon datings on natural historical sciences in Denmark: especially paleozoological and shore-line datings. Pact 49, 117-130.

Rößler, D., Moros, M. \& Lemke, W. 2011: The Littorina transgression in the southwestern Baltic Sea: new insights based on proxy methods and radiocarbon dating of sediment cores. Boreas 40, 231-241. Doi: 10.1111/j.1502-3885.2010.00180.x. 